\title{
The Investigation of the Housing Stock in Turkey and Japan According to the Non-Structural Seismic Risks
}

\author{
Deniz Demirarslan ${ }^{1, *}$ \\ ${ }^{1}$ Kocaeli Üniversitesi, Mimarlık ve Tasarım Fakültesi, İç Mimarlık Bölümü, 41100, Kocaeli
}

\begin{abstract}
Earthquake is a significant natural incident which harms the people by affecting the housing settlements, in which they live in, developed by the cultures of the societies. The accurate planning of the housing spaces and building them seismically safe decreases these harms of the earthquakes. Nonetheless, the household goods that we use inside affect the internal space planning because of their habitual use and thus also affect the building, and the people and household goods inside during the earthquake. When the damages occurred in Turkey and Japan are examined, which are both located on the significant seismic zones, it is observed that demolition, damage, and injuries are encountered more in Turkey. Learning to live with the earthquakes and designing earthquake resistant buildings have become a lifestyle in Japan. Undoubtedly, the effects of the traditional Japanese lifestyle on the contemporary internal design of the houses exist within this concept. With this purpose, in this paper, traditional and contemporary internal space habitual uses of Japan, which is accepted to solve its earthquake problems as regards to design, and Turkey, which has encountered great sufferings due to the earthquakes, are examined; and their differences and similarities were compared according to the non-structural earthquake hazards. Thus, a righteous solution according to the disaster management was aimed to be achieved in the study.
\end{abstract}

\section{$\underline{\text { Anahtar Sözcükler }}$}

Earthquake, Non-structural Earthquake Risk, Disaster Management, Marmara Earthquake, Housing Design, Furniture

\section{Türkiye ve Japonya'da Konutların Yapısal Olmayan Deprem Tehlikeleri Açısından İncelenmesi}

\section{Özet}

Deprem, toplumların kültürleri ile gelişen konut mekânlarını etkileyerek içinde yaşayan insanlara zarar veren önemli bir doğal afettir. Konut mekânlarının doğru planlanması ve depreme dayanıklı olarak inşa edilmesi deprem zararlarını azaltmaktadır. Ancak, kullandığımız eşyalar kullanım alışkanlıkları nedeniyle iç mekân planlamasını, deprem sırasında ise konut binalarını ve içindekileri etkilemektedir. Yeryüzünde önemli deprem kușakları üzerinde bulunan Türkiye ve Japonya'da meydana gelen hasarlar incelendiğinde ylkım, hasar, ölüm ve yaralanmaların Türkiye'de daha fazla olduğu gözlenmektedir. Japonya'da ise depremle yaşamayı ögrenmek ve depreme dayanıklı binalar tasarlamak bir yaşam şekli haline gelmiştir. Hiç kuşkuşuz bu konuda geleneksel Japon yaşam tarzının çağdaş konut iç mekânı tasarımına olan etkileri bulunmaktadır. Bu amaçla, bu makalede deprem sorununu tasarım açısından çözmüş bir ülke olarak kabul edilen Japonya ile deprem konusunda büyük acılar yaşayan Türkiye'nin geleneksel ve çağdaş konut iç mekân kullanım alışkanlıkları incelenerek aradaki farklılıklar ve benzerliklerin yapısal olmayan deprem tehlikesi yönünden incelenerek afet yönetimi açısından doğru bir çözüme ulaşılması hedeflenmiştir.

$\underline{\text { Keywords }}$

Deprem, Yapısal Olmayan Deprem Tehlikesi, Afet Yönetimi, Marmara Depremi, Konut Tasarımı, Mobilya.

\section{Introduction}

Japan and Turkey are the two countries that are presently located in the significant seismic zones in the world. It was observed that especially Kobe Earthquake of 1995 and Marmara Earthquake of 1999 (Figure 1) had caused significant damages in both countries. Thus, in Japan, various disaster management activities are carried out by the Earthquake Research Committee belonging to the Ministry of Education, Research, and Culture. Turkey, on the other hand, develops various earthquake scenarios, with the support of the countries having an advanced level of scientific researches- especially Japan-, before the expected great Istanbul earthquake; and conducts preparation works as regards to the field of disaster management. 

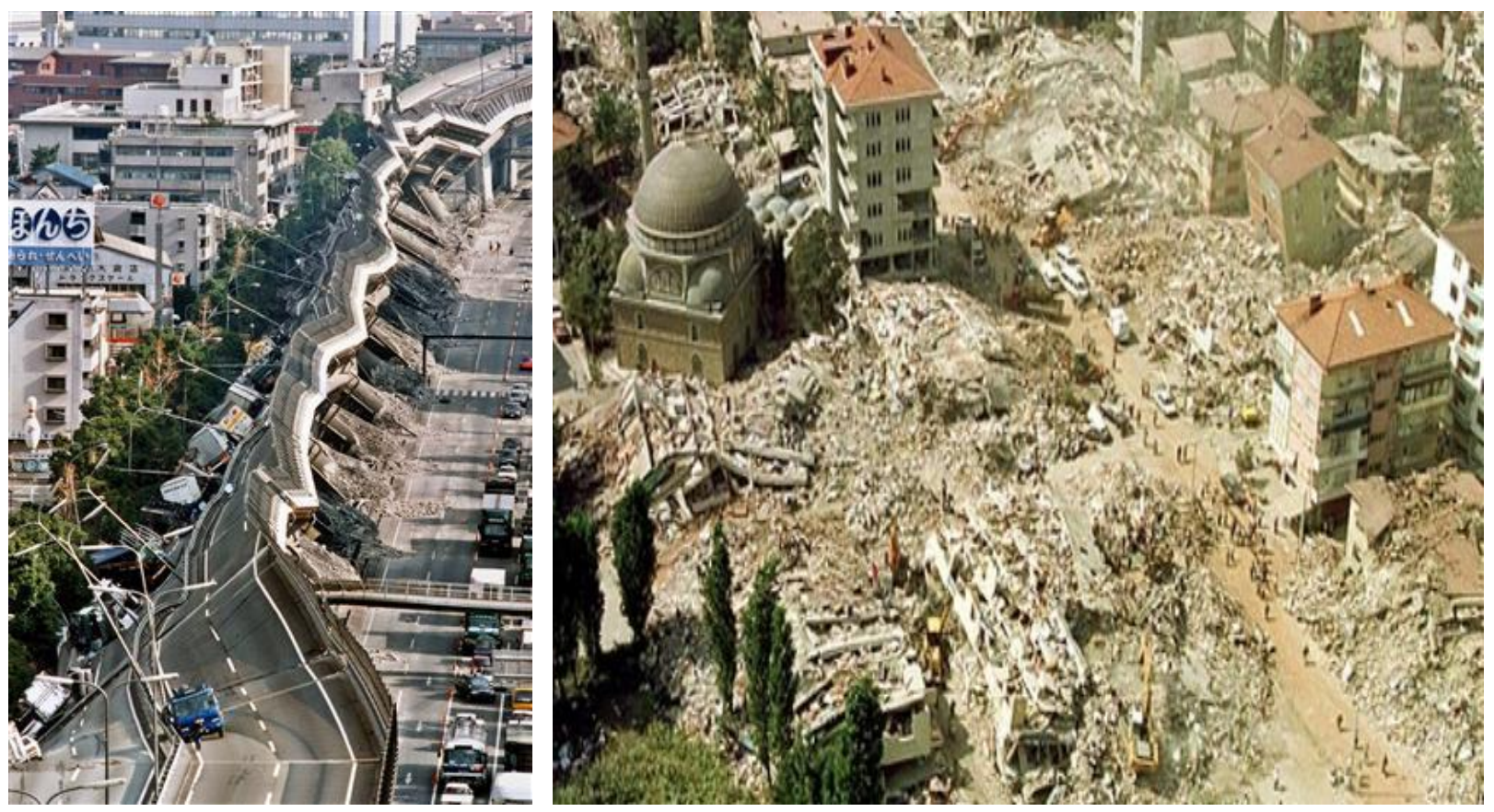

Figure 1: Kobe Earthquake of 1995 on left and Marmara Eathquake of 1999 on right (URL-1 2016; URL-2 2016)

Disaster management, according to Atl1's (2006) definition, is the pre-planning of all the potentials and researches for the prevention and reducing the harms of the disasters; being prepared for the disasters; and the coordination of emergency service activities during the disasters. The seismic risks can be classified into two groups, according to the disaster management field, as structural risks and non-structural risks. The structural risks are the dangers that would be caused by the structural systems of the buildings. Since they cause great demolitions and damages, they are dealt more in number as a research subject while the non-structural risks also cause various direct or indirect effects on the human safety and space. The non-structural risks are the dangers that would be caused by the internal space elements, except the elements belonging to the structural system of the building, such as every household goods, furniture, doors, windows, suspended ceilings, etc. The non-structural risks effects the people in every space; especially in the housing spaces. Therefore, the determination of the non-structural seismic risks and taking precautions against them plays a significant role in conducting the works to reduce the harms caused by the structural and non-structural seismic risks. Thus, the non-structural seismic risks should also be taken seriously. In this study, a conclusion as regards to the disaster management is aimed to be achieved by examining the internal space habitual uses in Japan, and then comparing them with the use of internal space in Turkey.

\section{Methodology}

The use of the furniture, equipments, and accessories, which constitute the non- structural risks, differs according to the cultural structures of the societies and time. The use of furniture and equipments affects the relations between the housing spaces, and thus, their structural systems. The housing buildings that are accordingly shaped can have more damageable structural systems; the spaces that are modified according to the requirements can become seismically vulnerable; or the accessories that are used in the internal space can cause injuries and deaths. Therefore there exists a need to determine the effectiveness level for the use of the housing internal spaces and the household goods. With this aim, within the concept of the study;

- As the first step, the reports conducted to examine the damages occurred in the two recent big earthquakes of Turkey and Japan, 1995 Kobe Earthquake and 1999 Marmara Earthquakes, and to determine the damages caused by the use of the internal space and household goods, by the various institutions, were investigated.

- In the second phase, the housing space and household goods of the traditional Japanese house were examined according to their major features; and the effects of these features on the contemporary housing spaces were identified.

- As the last phase, the features of the space and household goods of the traditional Turkish housing were substantially examined; and its reflections on the modern-day Turkish housing spaces were identified. In the conclusion section, the differences and similarities of the internal space habitual uses on the traditional and contemporary houses, which affect the disaster management works in Japan and Turkey, were identified; and suggestions to reduce the non-structural damages of the earthquake, as regards to the field of disaster management, were presented. 


\section{Damages Caused by the Non-Structural Risks in the 1995 Kobe and 1999 Marmara Earthquakes}

As mentioned by Nakabayashi and Ichiko's (2004) in their research, when the two big magnitude earthquakes occurred in the last quarter of the 20th century were examined, it was determined that both of the countries suffered great damages as can be seen in Table 1. Among these damages, the injuries and deaths caused by the collapse of the internal household goods, although not as much as in ratio as the collapse of the buildings, is a significant concept to be considered while taking precautions against the occurrence of the seismic damages within the process of conducting disaster management works.

Table 1: Statistics of Death and Injuries caused by the Earthquakes (Nakabayashi and Ichiko 2004)

\begin{tabular}{|c|c|c|}
\hline & TURKEY & JAPAN \\
& 17.8 .1999 & 17.1 .1995 \\
\hline Magnitude (USGS) & M 7.4 & M 7.2 \\
\hline Deaths (persons) & 18.373 & $6.4888^{*}$ \\
& & 43,792 \\
\hline Injuries (persons) & 48.901 & 3 \\
\hline Missing (persons) & unknown & 191,617 units \\
\hline Collapsed /Heavily & 96,000 units & 257,311 units \\
\hline Damaged & & \\
\hline Moderately Damaged & 108,889 units & \\
\hline
\end{tabular}

* Immediate fatalities before June 1995 announced by the Ministry of Welfare

** Earthquake damage related fatalities announced by the Fire defense Agency

Otani (1999) stated in his study that the buildings collapsed in the Kobe Earthquake were the old buildings belonging to the elderly. The majority of the collapsed buildings were the traditional houses built before World War II. Very few of the people killed in the earthquakes lived in the newly built houses. Damages occurred in the houses built after 1970s and 1980s but no incident of collapse was encountered. It was determined that the $1.2 \%$ among the causes of death in the Kobe Earthquake was the collapse of the household goods; and 65 people had been killed. The majority of the injuries, on the other hand, occurred as a result of the building collapses, due to the breakings of the beams, and the collapse of the household goods in the internal space. The majority of the injuries were the traumas occurred in arms, legs, and spine as mentioned in Maruo and Matumoto's (1996) study.

Kadıŏlu and Özdamar (2008), in their report conducted by the partnership of the Ministry of Internal Affairs and Japan Internal Cooperation Agency in Turkey, mentioned that the injury ratio caused by the non-structural risks in the Marmara Earthquake of 1999 was 50\% while the ratio of fatality was 3-4\%. These ratios include only the cases that are officially recorded. According to the unofficial records, these ratios were actually much higher. The household goods, which caused the most number of moderate and critical injuries, were determined in this report as closets in the bedrooms, glass china cabinets and TV cabinets in the living spaces, and closets in the kitchen. Moreover, it is stated that these collapsed furniture caused the deaths of the people as a result of suffocation. In the same report, fatalities and injuries were stated to be occurred as a result of the falling and sliding objects immediately after the earthquake; and the collapsed furniture were identified to be blocking the escapes since they close the exists. Especially the collapse of the closets in the bedrooms, occurrence of the trauma as a result of the leaping of the heavy books from their shelves in the bookcases, and the occurrence of serious cuts, as a result of the breaking glass caused by the falling of pictures and ornaments are among the events encountered during the earthquake.

It can be clearly seen that the first element that threats us in the housing internal spaces are the shaking and collapsing of the furniture and household goods. Even though the buildings do not collapse, the household goods used in the internal space can be the elements that carry a fatal risk and threats to the human life during the earthquakes. Otani (1999), in his research, stated that the cause of injuries and fatalities, occurred as a result of the collapse of the furniture in the Kobe Earthquake, was related to the housing designs and the type of furniture to be used inside. According to Otani's view, the housing spaces located inside the apartment blocks in Japan are limited living spaces with small meter square areas. On the other hand, heavy furniture and big household goods were used inside the houses in which the injuries and fatalities occurred. Therefore, raising awareness, as regards to the household goods and furniture use in the internal housing spaces, constitutes a significant basis of taking precautions against seismic damages and increasing the conscious of disaster management in the society. In the earthquakes experienced in Japan, however, the relatively lower ratio of injuries and fatalities as regards to the collapse of the household goods, compared with the ratios in Turkey, leads the researchers towards the investigation of the internal space and furniture habitual use in Japan and finding a solution by making comparisons with Turkey. 


\section{Internal Space and Furniture in Traditional and Contemporary Japanese Houses}

In the Japanese housing architecture, lifestyle, traditions, religion, and family structure, as well as geological features, are among the factors that create the spaces. The traditional Japanese house, according to Ayverdi (1972), is designed according to the "ma" philosophy which can be defined as forming a balance between nature and object.

The traditional Japanese domestic life is formed by "culture of sitting down on the floor". The "culture of sitting down on the floor" and "culture of looking at the floor" are among the factors that affect the formation of the Japanese internal space. According to this principle, the eye height of the humans is $1.60 \mathrm{~m}$. Thus, the taller household goods, used in the internal space, are not chosen during the design of these spaces. As can be seen from Figure 1, all of the internal spaces are modularly shaped according to the dimensions of floor mats called "tatami", ${ }^{2}$ which is a significant element of this culture, within a "Ken" ratio system". All of the spaces, excluding kitchen, bath, entrance, and hallway, are dimensioned and covered with the tatami as also mentioned by Yamamoto (1989). According the traditional Japanese architecture principle termed as "Kivari", the structural elements enlarged or became smaller in direct proportion with the loads they carried. Such that, if the dimensions of tatami used in this space were chosen, then the measurements of the structural elements were also determined.

The existence reason for every object in the space is its functionality. No design which does not have functionality was included in the internal spaces. The functions in the spaces were tried to be solved by using dynamic elements. The living space (i-ma), as mentioned in Yamamoto's (1989) study, is the main space in which the family lives their daily lives, and can be used for sitting, dining, cooking, and sometimes sleeping functions. The room, on the other hand, is again multi-functional (Figure 2). The portable household goods that are used in the rooms are stored in the built-in closets (oshiire) which are built during the construction of the building. The sliding doors, termed as "shoji" and "fusuma" and made up of one type of paper obtained from the rice, are located in the between the rooms; the integration of rooms and formation of flexible spaces can be enabled by opening the sliding doors when required. The perception of simplicity is dominant both in external and internal space design. Although the Western effect on the Japanese Architecture, which was influenced by the Christian Missioners, has been encountered since 1500s, this effect had been limited only within the public architecture.

Just as it is the traditional housing architecture, the family and functions are significant design factors in the contemporary Japanese housing architecture. A rational planning perception is encountered since function is also significant in the traditional housing architecture. Therefore, all the activities inside the houses were resolved with a minimal space approach. In the country, in which the households size was 3.19 in 2002 according to the Japanese Country Report (2007) data, the use of rental housing was common; and the apartment type urban houses had 1 or 2 rooms. The rooms had a size of 1 or 2 tatami. The separations between the rooms were again mostly established by sliding doors. Moreover, most of the Japanese Society continues to perform their activities at the floor level. As can be seen in Figure 3, one room in a contemporary Japanese house is generally furnished with a traditional style. Therefore, the non-structural seismic risks are decreased in the internal spaces of the houses.

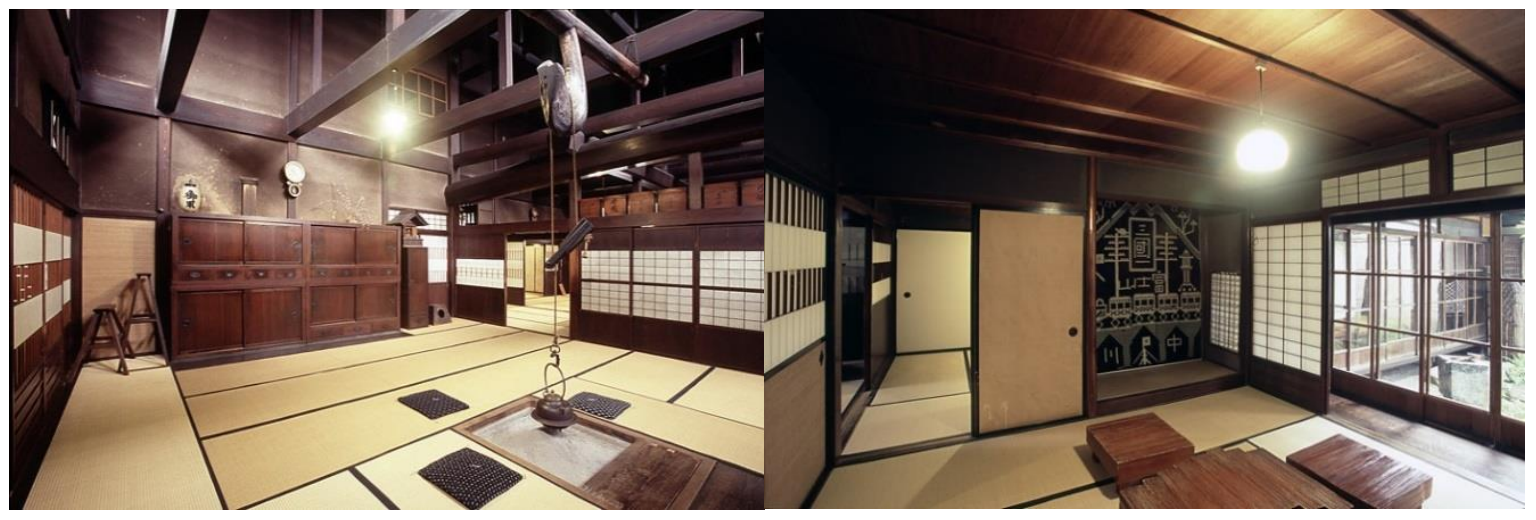

Figure 2: Internal Space in the Traditional Japanese Housing (URL-3 2016)

\footnotetext{
1 "Ma" is a Japanese word which can be roughly translated as "gap", "space", "pause" or "the space between two structural parts. In Japanese, ma, the word for space, suggests interval. It is best described as a consciousness of place, not in the sense of an enclosed three-dimensional entity, but rather the simultaneous awareness of form and non-form deriving from an intensification of vision.

${ }^{2}$ A tatami is a type of mat used as a flooring material in traditional Japanese-style rooms. Traditionally made using rice straw to form the core, the cores of contemporary tatami are sometimes composed of compressed wood chip boards or polystyrene foam. With a covering of woven soft rush straw, tatami are made in standard sizes, with the length exactly twice the width, an aspect ratio of 2:1. Usually, on the long sides, they have edging of brocade or plain cloth, although some tatami have no edging.

${ }^{3}$ The ken is a traditional Japanese unit of length, equal to six Japanese feet (shaku). The exact value has varied over time and location but has generally been a little shorter than 2 meters (6 ft 7 in). It is now standardized as $1 \frac{9}{11}$ meter.
} 


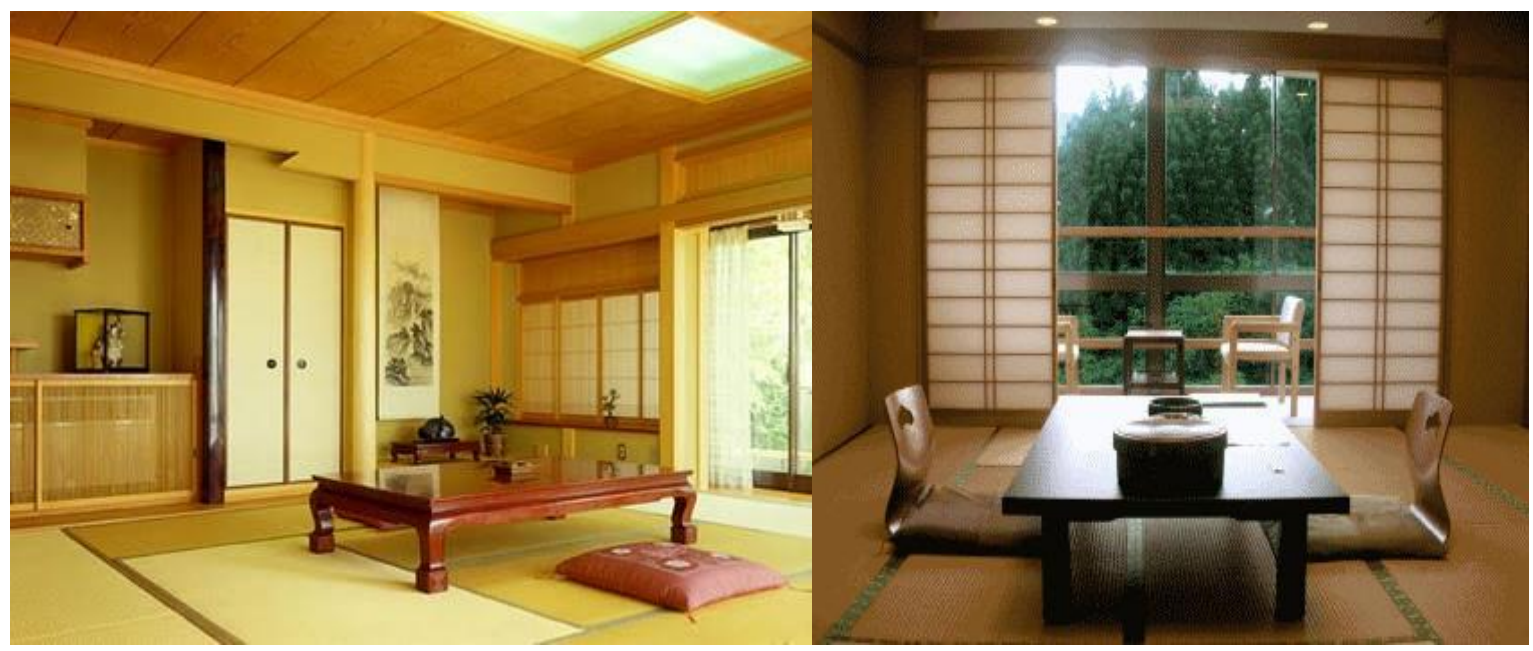

Figure 3: A Contemporary Japanese House Furnished with a Traditional Style (URL-4 2016)

Light and multi-functional furniture in small numbers were used in the traditional and contemporary Japanese houses in relation with the daily life habits, life styles, and customs. The TV units, refrigerators, Western style chairs and tables, and music sets are the symbols of Western life style. Nonetheless, these goods were also designed according to the customs in the Japanese lifestyle. Nowadays, the Japanese furniture production sector has a significant place in the world market. The furniture firms in the globalized world also meet the requirements of the Japanese society along with their Western style furniture production. The consumers in the Japanese market, according to the Japanese Household Consumption Report, prefer furniture having a style closer to traditional style, economic, functional, and safe. Demountable and modular furnitures were especially preferred by the housewives as stated in the Japan Furniture Trade report (1998). Even though Western style furniture has been used in the Japanese houses especially since the modernization period in the beginning of 20th century, they were observed to be used with a minimal space perception as well.

Tanyeli (2000), in his book about this subject, stated that the contemporary architects such as Tadao Ando designed houses suitable for Japanese "Wohnkultur", the sheltering norms, but they rarely used the structural features of the Japanese traditional architecture. Contemporary Japanese architects, such as Ando, prefer to design structures which would form spaces suitable for the style of life and contemporary requirements, by preserving the naturality of the material. Thus, the main principle of the contemporary Japanese housing architecture is the design of minimal space that constitutes the perception of functional, flexible, and dynamic space. In both traditional and contemporary Japanese houses, the aesthetic understanding while designing of the space was enabled by not ornamentation and lumpish furniture used in the internal space but by functional solutions.

\section{Internal Space and Furniture in the Traditional and Contemporary Turkish Houses}

Since the Turks had the feature of being a nomadic society before their emigration from the Central Asia to Anatolia, their sheltering spaces were planned with the philosophy of "being content with less". The traditional Turkish houses, constructed after they adopted a sedentary lifestyle, took their planning features from this nomadic lifestyle. One of the most significant features affecting the space formation in the traditional houses, which was developed with the plan types containing anteroom and atrium, is the patriarchal family structure as it is in the traditional Japanese lifestyle. Nevertheless, elderly and children in the family live under the same roof whereas every member of the family owns a separate house in the traditional Japanese family.

As can be seen Figure 4, mobile furniture are not used in the traditional Turkish houses as it is the case in the traditional Japanese house. Living, sleeping, and dining activities are similar in both of the societies and performed at the floor level or at a level close to floor. Therefore, the room belonging to a Turkish house is multi functional just like the living space (i-ma) of a Japanese house. All the mobile household goods are stored in the built-in closets with a system similar to the system in the Japanese house. All of the spaces in the traditional Turkish house is multi-functional and have a flexible planning approach. The dimensioning system of the Turkish house, which constitutes the base of Le Corbusier's Modulor dimensioning system, is based on the ergonomic and functional features. Since the height of 2.20 $\mathrm{m}$ in the internal space is the highest limit of a person's activity area, the use of furniture above this level is rare. 


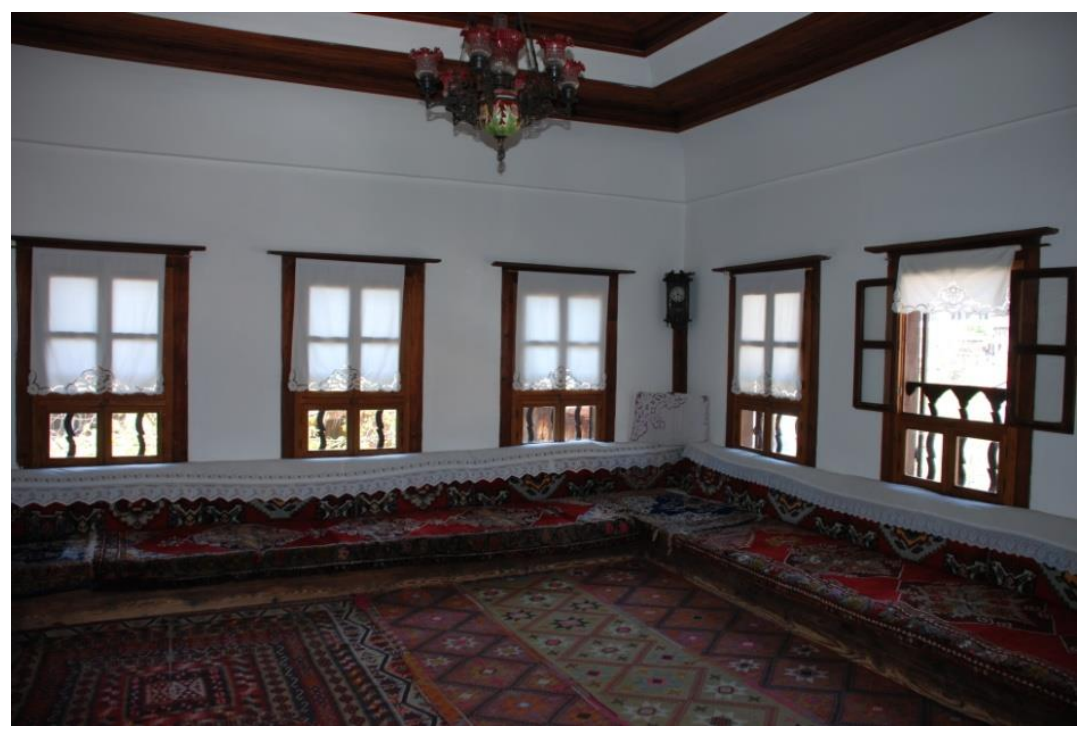

Figure 4: Internal Space in the Traditional Turkish House

The windows and doors are fixed in the traditional Turkish house conversely with the situation in the traditional Japanese house. Therefore, the entire relationship between the internal and external space is established with doors and windows.

The lifestyle of the Turkish society was separated from the traditional lifestyle as a result of the close relations formed with the European countries in the 19th century, as mentioned by Berkes (1975); and Western style of living was adopted in every level of the society. The furniture and household goods have been imported from Europe and bought by the society since the second half of the 19th century.

This situation, on the other hand, caused spatial changes in the traditional Turkish house. First, the spaces of the traditional Turkish house became single functioned; and then Western style furniture were started to be used. Nonetheless, when the traditional houses could not meet the requirements of the changing lifestyle, the Western style multi storied apartment style houses were started to be constructed. The plan schema consisting of 2 or 3 rooms and a living room established itself as the common housing stereotype in the contemporary Turkish housing architecture. The extended family structure, on the other hand, was transformed into the immediate family structure. Although the household size was decreased, the sizes of the houses did not change. According to the 2014 data, the average household population in Turkey was 3,6 whereas the average house/flat size was between 100-120 m² (URL-5 2016). The dimensions of the furniture used in the internal space and their features, instead of traditional architecture and dimensioning system, were taken into account during the planning of the contemporary houses (Figure 5).

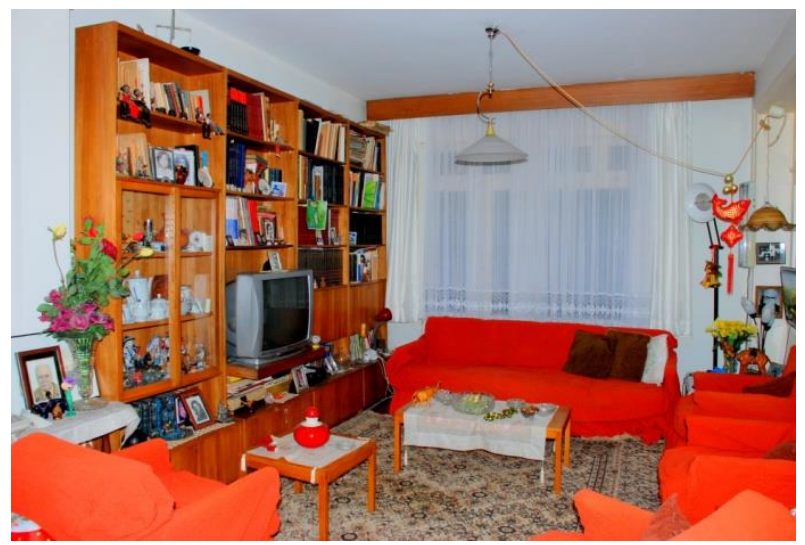

Figure 5: Internal Space in the Contemporary Apartment Style Turkish House

The use of household goods in the traditional style still continues in the rural regions. Nonetheless, the use of Western style furniture changed the consumption models, as can be seen in Figure 4; and spaces full of furniture affected the structures of the houses as an element which determines the house owner's status in the society. On the other hand, Western style furniture production also increased in Turkey. According to the Furniture Producer's Association (MOSDER) data published in the URL-6 (2016), the furniture production in Turkey became a big sector of 
$\$ 7.5$ billion in 2009. According to Turkish Statistical Institute the furniture production in Turkey is TL 10.4 billion in 2010 (URL-6 2016). Furniture consumption in Turkey, on the other hand, is annually 15 Euros per person. Although a decrease in the consumption amount was observed because of the crisis encountered, according to the data of Turkish Economy Institute in 2002, the amounts spent on furniture and household goods constitute the $6.9 \%$ and $8.1 \%$ of the total consumption costs in the urban and rural regions, respectively. The houses are still being planned to meet this dense use of household goods requirements. Therefore, housing spaces with the furniture bought according to the frequently changing fashions and trends accelerated the construction of the high-rise apartment blocks. The present houses, with the effect of communication devices such as TV, were started to be remodelled according to this new lifestyle. Since most of these remodelings were performed uncontrollably and unconsciously, structural damages were encountered. The majority of the demolished and damaged buildings in the earthquake of 1990 were determined to be buildings that were remodeled unconsciously (Demirarslan 2003). Moreover, the enthusiasm towards the Western style living in the contemporary Turkish houses were so effective that more care was taken, not to the resistance and the structural quality of the building, but to the internal furnishing features and comfort conditions. This condition, however, decreased the structural quality; and the structure was not considered important although significant amount of money was spent on the comfort. The structural calculations could not be conducted as required; and fraudulent implementations were encountered in the use of building material.

\section{Findings}

According to the investigation conducted, as can be seen in Table 2, since non-structural seismic risks are caused by the collapse of the household goods and furniture and spatial elements, the major reasons for the occurrence of these damages are closely related to the lifestyle, family structure, changes in the functions of the housing spaces, the denseness of the household goods, materials used, relation between form and space, and therefore related to the design of the internal space elements. Consequently, there exists a need to educate the societies, as regards to the use of internal space in the houses, to decrease these damages. Thus, education is also significant factor for the occurrence of these damages.

It was determined, when the damages occurred in the two significant earthquakes were examined, that the usage type of the internal spaces in the houses, and furniture and household goods had various effects on the people and on the buildings. The works related to the disaster management, along with the scientific researches, are conducted in Japan. The Japanese society is first educated about this subject with the help of communication devices. The minimum conditions, regarding the use of the buildings, were determined by Building Standards Institute in Japan (Atl1 2006). Within the disaster management works conducted by Ministry of Japanese Settlement, a requirement for the immobilization of the large volume goods in the internal spaces, such as closets, bookshelves, and tables; with the aim of preventing their easy collapse, and accordingly, injuries and loss of lives caused by these collapses. The ratio of people who immobilized the furniture and household goods was 8.5\% in July 1991 while this ratio, following the Kobe Earthquake, was $14.8 \%$ in September 2001 according to the report conducted by Japanese Government Office in September 2004 (Nishikawa 2004).

When the studies conducted in Turkey were examined, it was observed that the precautions were insufficient. The condition of the household goods used by the disaster survivors in the 1999 Marmara Earthquake was determined in a research conducted by Kocaeli University. It was determined in Canbulat and Erturk's report (2003) that 86.2\% of the earthquake victims did not immobilize their household goods in their damaged houses. Furthermore, in the same report, it was stated that $79.2 \%$ of disaster survivors did not immobilize their large volume furniture in their temporary houses; and $46.7 \%$ of them did not perform any work regarding the fastening of their household goods. Although educational works, within the disaster management activities performed by the Turkish Red Crescent Association, at the schools in Istanbul were initiated in 2004 for the aim of reducing the non-structural damages in Turkey, Turkish society is still not aware of the non-structural seismic risks.

It was observed that the people continued to use large volume household goods even after the big earthquakes in Turkey; and they continued to keep household goods densely inside their houses even if they do not need them. The consumption of household goods and furniture, especially, continues at full steam. The major cause for this situation is the differences in the lifestyles of two societies. Both of the societies were building their houses with entirely functional solutions, by using fewer household goods, in their traditional lives. Both of the traditional houses are the shells formed by the shaping of the internal space. Nonetheless, the life styles of the societies changed as a result of the modernization and westernization movement encountered in the Turkish society since the 19th century. This condition, on the other hand, with the wide-spreading of the household goods and Western style furniture, changed first the internal space of the houses, then planning of the houses, house typology, and even planning of the cities.

The westernization in Japan, however, was handled differently. The better qualities of the modernization, encountered especially in the 20th century, were adopted by the Japanese society; and were tried to be matched up with the traditional Japanese life. The Japanese traditional life has been changed due to the fast development of the technology but the life philosophy did not change. The functionality constituted the base of the housing design, as it has been for the traditional life, also in the modern houses. The functionality brings forth the use of fewer but multi 
functional household goods whereas the modern houses aim to service more family members in a smaller space. Contemporary Japanese person, as a result of the earthquakes experienced, is more attentive to use fewer, light, functional, and modular furniture, and assuredly immobilizes the large volume furniture.

Table 2: Comparison of Turkish and Japanese Houses According to the Non-Structural Damages

\begin{tabular}{|c|c|c|c|c|}
\hline \multirow{2}{*}{ Parameter } & \multicolumn{2}{|c|}{ Turkish Houses } & \multicolumn{2}{|c|}{ Japanese Houses } \\
\hline & Traditional & Contemporary & Traditional & Contemporary \\
\hline Family structure-space relation & Extended family & $\begin{array}{c}\text { Immediate } \\
\text { family }\end{array}$ & Immediate family & $\begin{array}{c}\text { Immediate } \\
\text { family }\end{array}$ \\
\hline Function- space relation & Multi-functional space & $\begin{array}{c}\text { Single } \\
\text { functioned } \\
\text { space }\end{array}$ & \multicolumn{2}{|c|}{ Multi-functional space } \\
\hline Usage- space relation & Flexible and dynamic space & $\begin{array}{l}\text { Fixed and } \\
\text { static space }\end{array}$ & \multicolumn{2}{|c|}{ Flexible and dynamic space } \\
\hline Household goods- space relation & $\begin{array}{c}\text { Use of goods in small } \\
\text { numbers }\end{array}$ & $\begin{array}{l}\text { Use of goods } \\
\text { in large } \\
\text { numbers }\end{array}$ & \multicolumn{2}{|c|}{ Use of goods in small numbers } \\
\hline Furniture- space relation & $\begin{array}{l}\text { The large furniture is built } \\
\text { together with the structure } \\
\text { while the other furniture } \\
\text { were portative. }\end{array}$ & $\begin{array}{l}\text { Western style } \\
\text { mobile } \\
\text { furniture is } \\
\text { used. }\end{array}$ & $\begin{array}{l}\text { The large furniture } \\
\text { is built together } \\
\text { with the structure } \\
\text { while the other } \\
\text { furniture was } \\
\text { portative. }\end{array}$ & $\begin{array}{l}\text { Furniture that } \\
\text { is less in } \\
\text { number and } \\
\text { also modular } \\
\text { is used. }\end{array}$ \\
\hline Material- space relation & Plain & Dashing & \multicolumn{2}{|c|}{ Plain } \\
\hline Form- space relation & $\begin{array}{l}\text { Life style and ratio systems } \\
\text { are effective. }\end{array}$ & $\begin{array}{l}\text { Showing off } \\
\text { and Western } \\
\text { admiration is } \\
\text { effective. }\end{array}$ & \multicolumn{2}{|c|}{$\begin{array}{l}\text { Life style and ratio systems are } \\
\text { effective. }\end{array}$} \\
\hline Perception of space design & Minimal & $\begin{array}{l}\text { Densely } \\
\text { furnished with } \\
\text { household } \\
\text { goods. }\end{array}$ & \multicolumn{2}{|c|}{ Minimal } \\
\hline $\begin{array}{l}\text { Door- window- separating element- } \\
\text { space relation }\end{array}$ & Heavy material & $\begin{array}{l}\text { Heavy } \\
\text { material }\end{array}$ & \multicolumn{2}{|c|}{ Light material } \\
\hline Education- space relation & $\begin{array}{l}\text { Conscious design against the } \\
\text { natural incidents }\end{array}$ & $\begin{array}{l}\text { No conscious } \\
\text { design against } \\
\text { the natural } \\
\text { incidents }\end{array}$ & \multicolumn{2}{|c|}{$\begin{array}{l}\text { Conscious design against the natural } \\
\text { incidents }\end{array}$} \\
\hline
\end{tabular}

\section{Conclusions and Suggestions}

The precautions to be taken regarding the life styles of the societies, as a result of studying the Japanese case, are mentioned as below:

- The houses should have internal spaces organized with a flexible and minimal approach that can change with the change in the requirements.

- The plans of the houses should be freed from the "stereotypical" plan perception; and plan types suitable for the lifestyles of the families and household size should be developed.

- If the existing houses are to be remodelled because they do not meet the needs, then the necessary evaluations related to the structural statistics should be performed.

- The traditional designs of the societies should be re-interpreted, according to the contemporary designs, during the design of the housing spaces and the equipment to be used inside it.

- The use of functional furniture, instead of consumption of furniture for the purpose of showing off, should be aimed.

- The use of modular furniture should be encouraged.

- The density of using household goods in the internal spaces of the house should be decreased in the direction of the needs.

- High and heavy furniture should not be used in the internal space.

- The large furniture should be resolved along with the structure as it is the case in the traditional houses examined.

- The people should be educated about the immobilization of large household goods and furniture in their houses. The immobilization is a significant subject since the household goods forms survivable voids in the buildings 
collapsed during the earthquakes. Moreover, the design of the objects which would oscillate during the shaking should be dealt with attention.

- The subjects of earthquake resistance and prevention of the damage should be taken into consideration in the furniture production.

- The materials that could break and harm the humans should not be preferred especially in the furniture production. It is significant that light and highly durable materials should be used.

\section{References}

Atlı A., (2006), Afet Yönetimi Kapsamında Deprem Açısından Japonya Ve Türkiye Örneklerinde Kurumsal Yapılanma, Asil Yayınları, Ankara, 320ss.

Ayverdi A., (1972), Japonya Mimarlı̆̆ı Mekanı: Özellikle İç Mekan Kuruluşuna Yaklaşım, İstanbul Teknik Üniversitesi Yayını, İstanbul, 285ss.

Berkes N., (1975), Türk Düşününde Batı Sorunu, Bilgi Yayınevi, İstanbul, 303ss.

Canbulat T., Ertürk F., (2003), İzmit Depreminde Evi Zarar Gören Ailelerin, Geçici ve Kalıcı Konutlardaki Yaşam Serüvenlerinin Bina-Mobilya-Çevre Açısından Incelenmesi, Küçükçekmece ve Yakın Çevresi Teknik Kongresi "Deprem ve Planlama", 08-10 Ekim, İstanbul.

Demirarslan D., (2003), Yaşamsal Ihtiyaçlar Doğrultusunda Kullanıcıların Proje ve Uygulama Süreçlerinde Bina İç Mekanlarında Yaptıkları Değişikliklerin Depremde Ortaya Çıkan Bina Hasarlarına Etkileri, Kocaeli Deprem Sempozyumu, 12-14 Mart, 2003.

Japanese Country Report, (2007), Konya Ticaret Odası Etüd Araştırma Servisi, Konya.

Japan Furniture Trade New, (1998), IMI, Japanese furniture market outlook, http://furniture-www.com/tradenew/furtrad3.htm.

Kadıoğlu M, Özdamar E., (2008), Afet Zararlarını Azaltmanın Temel Ilkeleri, JICA Türkiye Ofisi, Yayın No: 2, Ankara, 368ss.

Maruo S., Matumoto M., (1996), Spinal fractures resulting from the 1995-great Hanshin earthquake of the Kobe-Osaka area of Japan, Spinal Cord, 34(7), 382-386.

Nakabayashi I., Ichiko T., (2004), A comparative study of built-up area reconstruction measure and strategy among earthquake disasters of Hanshin Awaji (Japan), east marmara (Turkey) and 921 Chi-chi (Taiwan). Comparative study on urban reconstruction process after earthquake among Turkey, Taiwan, Japan, The Japan Society for the Promotion of Science (JSPS) for Grants-in-Aid for Scientific Research (A) 2001-2003, 5-13.

Nishikawa S., (2004), Disaster Management in Japan, Director General for Disaster Management, Cabinet Office, Government of Japan, Tokyo, Japan, 52ss.

Otani S., (1999), Disaster mitigation engineering-The Kobe earthquake disaster, JSPS Seminar on Enginnering in Japan at the Royal Society, London, on September 27, 1999, 1-12.

Tanyeli U., (2000), Tadao Ando, Boyut Yayın Grubu, İstanbul, 128ss.

URL-1, (2016), https://tokyo5.files.wordpress.com/2009/01/kobe02.jpg, [Erișim 08 Haziran 2016]

URL-2, (2016), http://www.haberler.com/marmara-depremi-nin-15-yili-6382697-haberi/, [Erişim 08 Haziran 2016]

URL-3, (2016), http://www.orientalarchitecture.com/japan/takayama/kusakabe_gallery.php?p=kusakabe05.jpg [Erişim 06 Haziran 2016]

URL-4, (2016), http://www.flickr.com/photos/tanaka_juuyoh/2886383047/, [Erişim 06 Haziran 2016]

URL-5, (2016), http://www.tuik.gov.tr, [Erișim 06 Haziran 2016]

URL-6, (2016), Türkiye Mobilya Ürünleri Meclisi Sektör Raporu, http://www.tobb.org.tr/Documents/yayinlar/2014/mobilya_ sektor_raporu_tr_int.pdf, [Erișim 06 Haziran 2016]

Yamamoto T., (1989), Geleneksel Türk ve Japon Evlerinin Mekansal ve Yapısal Açıdan Karşılaştırılması ve Koruma Yöntemlerinin Incelenmesi, Yüksek Lisans Tezi, Mimar Sinan Güzel Sanatlar Üniversitesi, İstanbul. 